\title{
Study on the Interaction between Morin-Bi(III) Complex and DNA with the use of Methylene Blue Dye as a Fluorophor Probe
}

\author{
Ali A. Ensafi ${ }^{*, a}$, Reza Hajian ${ }^{a}$ and Sara Ebrahimi ${ }^{b}$ \\ ${ }^{a}$ Department of Chemistry, Isfahan University of Technology, Isfahan, 84156-83111, Iran \\ ${ }^{b}$ Department of Chemistry, University of Arak, Arak, 38156-879, Iran
}

\begin{abstract}
Com base em nossa investigação, ambos os complexos, morin-Bi(III) e Morin, podem vincularse ao DNA, embora a natureza da ligação seja diferente para cada um deles. Na presença e ausência do DNA, o morin-Bi(III) mostrou características espectrais diferentes, o que está de acordo com as observadas para outros intercaladores. Neste trabalho, a interação do complexo morin-Bi(III) com o DNA de timo de vitela foi investigada com o uso do azul de metileno (MB), como uma sonda de corante espectral e aplicação de espectrofotometria UV-Vis, espectroscopia de fluorescência e voltametria cíclica. A proporção de 2:1 do complexo de morin-Bi(III) foi calculada pela espectroscopia UV-Vis (método da razão molar). Observou-se que o sinal de fluorescência do complexo Bi(III)-morin é aumentado com a adição de DNA enquanto que o sinal do morin é diminuído com adição de DNA. O sinal de fluorescência do complexo-DNA desaparece pela adição de MB, o que confirma o deslocamento do complexo com MB. Os estudos de voltametria cíclica confirmam a reação de intercalação. Os resultados mostraram que somente o complexo de morin-Bi(III) pode intercalar-se em dupla hélice com o DNA. A constante aparente do complexo morin-Bi(III) com o DNA é de $2.8 \times 10^{4} \mathrm{~L} \mathrm{~mol}^{-1}$, enquanto que o morin liga-se por um modelo de não-intercalação.
\end{abstract}

Based on our investigation, although both morin-Bi(III) complex and morin can bind to DNA, the nature of the binding was found to be different for each of them. In the presence and absence of the DNA, the morin-Bi(III) complex shows different spectral characteristics which agree with those observed for other intercalators. In this work, the interaction of morin-Bi(III) complex with calf thymus DNA was investigated with the use of methylene blue (MB) dye as a spectral probe and application of UV-Vis spectrophotometry, fluorescence spectroscopy and cyclic voltammetry. The 2:1 morin-Bi(III) complex ratio was calculated by UV-Vis spectroscopy (mole ratio method). The fluorescence signal of Bi(III)-morin complex is increased with DNA addition whereas the fluorescence signal of Morin is decreased with DNA addition. The fluorescence signal of the DNA-complex is quenched by addition of MB which confirms the displacement of the complex with MB. Cyclic voltammetry studies confirm the intercalation reaction. The results showed that only morin-Bi(III) complex can intercalate into the double helix of the DNA. The apparent binding constant of morin-Bi(III) complex with DNA is found to be $2.8 \times 10^{4} \mathrm{~L} \mathrm{~mol}^{-1}$, while morin binds in a non-intercalation mode.

Keywords: morin-Bi(III) complex, calf thymus DNA, methylene blue, UV-Vis spectrophotometry, cyclic voltammetry, fluorescence spectrometry, MCR-ALS.

\section{Introduction}

Interaction between DNA and drug molecules is of current general interest and importance, ${ }^{1,2}$ especially for the designing of new DNA-targeted drugs and the screening of these in vitro.

\footnotetext{
*e-mail: ensafi@cc.iut.ac.ir
}

Flavonoids have recently attracted a great interest as potential therapeutic agents against a large variety of diseases, such as anti-viral, anti-allergic, anti platelet and anti-inflammatory, and possible protective effects against chronic disease. ${ }^{3-5}$ Anti-tumor promoting activity has also been reported for flavonoids therefore, proving useful as chemopreventive agents in human carcinogenesis. ${ }^{6-9}$ These polyphenolic compounds, ubiquitous in plants, are also 
frequent components of major dietary constituents. In this context, it is generally considered that these flavonoids form coordination complexes with some essential trace metals, and it is believed that this is the active form of the compound, which is medicinally beneficial. ${ }^{10}$

Morin (Figure 1) as a flavonoid and its complexes exhibit different antitumour activities which led us to consider the interaction of the two complexes and morin with calf thymus DNA. Because nucleic acid is usually the target of some antitumour reagents in the organism, these reagents react with DNA thereby changing the replication of DNA and inhibiting the growth of the tumor cell. There is, therefore, considerable interest in the design of small molecules which react at specific sites along the DNA strand as reactive models for protein-nucleic acid interactions, in developing new probes of DNA structures, as an aid to drug design and as tools in molecular biology. ${ }^{11-14}$<smiles></smiles>

Figure 1. Molecular structure of morin.

Barton et al. ${ }^{14}$ have studied the interaction of enantiomers of $\mathrm{Ru}(\mathrm{phen})_{3}{ }^{3+}$ with various $\mathrm{DNA}$; the results led them to the conclusion that there are two modes of interaction, intercalative and electrostatic binding. The $\Delta$-isomer favors binding to the B-form DNA by intercalative fashion, while the $\Lambda$-isomer is not favored. They found that the intercalating ability appears to increase with the planarity of ligands.

Many techniques, such as UV-Vis spectrophotometry, ${ }^{15}$ fluorescence spectroscopy, ${ }^{16}$ circular $^{17}$ and linear dichroism spectroscopy, ${ }^{18}$ mass spectrometry, ${ }^{19} \mathrm{X}$-ray crystallography ${ }^{20}$ and voltammetry ${ }^{21}$ have been used to study the binding properties between metal complexes and DNA.

As a planar dye molecule, methylene blue (MB) (Figure 2) has long been used for biological straining and diagnosis of disease including carcinoma. ${ }^{22-24}$ It is a phenothiazinyl dye, which is a kind of photosentizer drug molecule showing promising applications in photodynamic therapy (PDT) for anticancer treatment. ${ }^{25}$ The interaction of methylene blue<smiles>CN(C)c1ccc2nc3ccc(=[N+](C)C)cc-3sc2c1</smiles>

Figure 2. Molecular structure of methylene blue. with DNA has been studied with various methods..$^{26-30}$ Most studies indicated that (at low ionic strength buffer and low concentration of DNA) the major binding mode of MB with DNA was through intercalation. ${ }^{28-31}$ Moreover, MB has a low toxicity; data from material Safety Data Sheet of Vanderbilt Environmental Health \& Safety (VEHS) show that $\mathrm{MB}$ is slightly hazardous in case of skin contact, eye contact, ingestion, and inhalation but there is no evidence which shows that $\mathrm{MB}$ is a carcinogenic compound. ${ }^{32}$

We were interested in understanding the correlation between different antitumour activities of morin and its complexes with the DNA binding mode and its affinity. Recently, bismuth has been used in medicines for the treatment of helicobacter pylori-induced gastritis. However, a number of toxic effects in humans have been attributed to bismuth compounds such as, nephropathy, osteoarthropathy, hepatitis, and neuropathology. ${ }^{33}$ As the use of bismuth in medicines is increasing, it has spread in the environment and the exposure of organisms to bismuth has increased. ${ }^{34}$

In this report we explore the interaction of the morin plus its complex (Bi-complex) with calf thymus DNA, using spectrophotometric, fluorimetric and cyclic voltammetry methods. The aim of this study is to find a relation between the antitumour properties of the complex and the mode of DNA binding. The results of the study are that morin binds in a non-intercalating mode while the complex binds by intercalation. MB has been used as a probe for comparison of the complex and its interaction with DNA. The study in this report offers an opportunity to understand how the structure of molecules affects their binding mode and binding affinity to DNA. This will help us design new complexes which have biological and antitumour activity.

\section{Experimental}

\section{Reagents}

All the chemicals were of analytical grade and were purchased from Aldrich. Doubly distilled water was used throughout.

Stock solution $\left(1.0 \times 10^{-3} \mathrm{~mol} \mathrm{~L}^{-1}\right)$ of $\mathrm{Bi}(\mathrm{III})$ was prepared by dissolving $0.0485 \mathrm{~g}$ of $\mathrm{Bi}(\mathrm{III})$-nitrate $.5 \mathrm{H}_{2} \mathrm{O}$ in $0.1 \mathrm{~mol} \mathrm{~L}^{-1} \mathrm{HCl}$ and diluted with water in a $100 \mathrm{~mL}$ volumetric flask.

A $1.0 \times 10^{-3} \mathrm{~mol} \mathrm{~L}^{-1} \mathrm{MB}$ solution was prepared daily by dissolving $0.0374 \mathrm{~g}$ methylene blue. $3 \mathrm{H}_{2} \mathrm{O}$ in water and the solution was diluted to $100 \mathrm{~mL}$ with water in a $100 \mathrm{~mL}$ volumetric flask. The solution was kept in a refrigerator at $4{ }^{\circ} \mathrm{C}$ and in dark. More dilute solutions were prepared by serial dilution with water. 
A $1.0 \times 10^{-3} \mathrm{~mol} \mathrm{~L}^{-1}$ morin solution was prepared daily by dissolving $0.0302 \mathrm{~g}$ morin. $\mathrm{H}_{2} \mathrm{O}$ in ethanol: $\mathrm{H}_{2} \mathrm{O}(1: 1)$ and diluted to $100 \mathrm{~mL}$ with water in a $100 \mathrm{~mL}$ volumetric flask. The solution was kept in a refrigerator at $4{ }^{\circ} \mathrm{C}$ in dark. More dilute solutions were prepared by serial dilution with doubly distilled water.

Calf thymus DNA was used as received without further purification. Its concentration was determined spectrophotometrically using the molar coefficient value, $\varepsilon_{260}=6600 \mathrm{~L} \mathrm{~mol}^{-1} \mathrm{~cm}^{-1} .{ }^{35} \mathrm{~A} 1.76 \times 10^{-4} \mathrm{~mol} \mathrm{~L}^{-1} \mathrm{DNA}$ was prepared by dissolving $0.010 \mathrm{~g}$ of calf thymus DNA in $0.010 \mathrm{~mol} \mathrm{~L}^{-1}$ acetate buffer and $0.05 \mathrm{~mol} \mathrm{~L}^{-1}$ sodium chloride solution ( $\mathrm{pH} 3.2)$ in a $25 \mathrm{~mL}$ volumetric flask.

The $\mathrm{pH}$ of all solutions was adjusted with the acetate buffer $\left(0.01 \mathrm{~mol} \mathrm{~L}^{-1}, \mathrm{pH} 3.2\right)$ in the presence of $0.05 \mathrm{~mol} \mathrm{~L}^{-1}$ sodium chloride.

\section{Apparatus}

Voltammetric measurements were carried out using a Metrohm instrument, Model 797 VA, computrace with stand three-electrodes containing a glassy carbon as a working electrode, a carbon rod as an auxiliary electrode and an $\mathrm{Ag} / \mathrm{AgCl}\left(3.0 \mathrm{~mol} \mathrm{~L}^{-1} \mathrm{KCl}\right)$ reference electrode.

UV-Vis absorption spectra were measured on an Agilent UV-Vis spectrophotometer, JASCO, using of $1.0 \mathrm{~cm}$ quartz cells.

All spectrofluorometry assays were made on a spectrofluorometer, JASCO, equipped with a xenon lamp and a $1.0 \mathrm{~cm}$ quartz cell. Both excitation and emission slits were set at $5 \mathrm{~nm}$, and the scan rate at $500 \mathrm{~nm} \mathrm{~min}^{-1}$. A Pentium IV (2.0 MHz) computer controlled all of the settings and data processing.

The IR spectra within the range of $4000-500 \mathrm{~cm}^{-1}$ were made in $\mathrm{KBr}$ pellets on a FT-IR Paragon-1000 spectrophotometer (Perkin-Elmer).

A pH-meter (Corning, Model 140) with a double junction glass electrode was used to check the $\mathrm{pH}$ of the solutions.

All experiments were carried out at room temperature $\left(25 \pm 1{ }^{\circ} \mathrm{C}\right)$ in $0.01 \mathrm{~mol} \mathrm{~L}^{-1}$ acetate buffer solution, $\mathrm{pH} 3.2$, containing $50 \mathrm{mmol} \mathrm{L}^{-1} \mathrm{KCl}$.

\section{Synthesis of the morin-Bi(III) complex for IR spectroscopy}

Stock solution $(50 \mathrm{~mL})$ of bismuth ions $\left(1.0 \times 10^{-2} \mathrm{~mol} \mathrm{~L}^{-1}\right)$ was added into $150 \mathrm{~mL}$ of hot saturated solution of morin in methanol $\left(2 \times 10^{-2} \mathrm{~mol} \mathrm{~L}^{-1}\right)$ and the result solution was diluted with water to a $1: 1 \mathrm{MeOH} / \mathrm{H}_{2} \mathrm{O}$ ratio. The solution was stirred and the $\mathrm{pH}$ was fixed 3.2 with $0.1 \mathrm{~mol} \mathrm{~L}^{-1}$
$\mathrm{NaOH}$ solution. Then the mixture was heated to $60{ }^{\circ} \mathrm{C}$ for $1 \mathrm{~h}$ and left at room temperature for $24 \mathrm{~h}$. The precipitate, after being washed several times with methanol:water (1:1) solution, was centrifuged and dried in air at room temperature.

\section{Preparation of the glassy carbon electrode}

The glassy carbon electrode surface was polished with $0.2 \mu \mathrm{m}$-alumina powder and then cleaned ultrasonically for $5 \mathrm{~min}$ in doubly distilled water. The electrode was then transferred into a blank buffer solution, and a continuous voltammetric scan with a scan rate of $50 \mathrm{mV} \mathrm{s}^{-1}$ was carried out.

\section{Theory of MCR-ALS}

Data obtained from the spectroscopic monitoring of the chemical system by changing $\mathrm{pH}$ can be gathered in a data matrix $\mathrm{D}(m \times n)$ in which rows are the spectra recorded and columns are the different $\mathrm{pH}$. In general, the goal of resolution methods ${ }^{36}$ is the decomposition of the data matrix $\mathrm{D}$ according to equation (1):

$\mathrm{D}=\mathrm{CS}^{\mathrm{T}}+\mathrm{E}$

where $\mathrm{C}$ is a $m \times k$ matrix, $\mathbf{S}$ is a $n \times k$ matrix, $\mathrm{E}$ is a $m \times$ $n$ matrix, $k$ is the number of factors directly related to the chemical species or conformations present in different $\mathrm{pH}$, i.e., $k$ corresponds to the spectroscopically active species or conformations. Therefore, columns of $\mathrm{C}$ describe the concentration profiles for the $k$ different species in the $\mathrm{pH}$ range and the rows of $S^{\mathrm{T}}$ matrix describe the pure spectra for each one of these $k$ components. Finally, E is the matrix of residuals not explained by the multiplication of $\mathrm{C}$ and $\mathrm{S}^{\mathrm{T}}$.

To have a meaningful solution from the curve resolution decomposition, it is necessary to make some assumptions about the signals obtained such as bilinearity, nonnegativity, unimodality, and closure. One of the most interesting techniques is evolving factor analysis (EFA). ${ }^{37}$ Taking advantage of the evolutionary structure of the acquired data, evolving factor analysis provides an estimation of information (concentration profiles), concerning the windows of existence of every component in the mixtures existing at any $\mathrm{pH}$ during the process.

Multivariate curve resolution-alternating least squares (MCR-ALS) iteratively finds the matrices of concentration and spectral profiles, and can be used to obtain a better estimation of profiles. ${ }^{38}$ In this method, the both $\mathrm{C}$ and $\mathrm{S}^{\mathrm{T}}$ matrices are optimized at each iterative cycle and have no priority over each other. The first step in application of 
MCR-ALS is determination of the number of compounds in $\mathrm{D}$. The number of compounds in $\mathrm{D}$ can be determined using PCA or can be known beforehand. Then, knowing the number of components initial estimates are calculated, for example a rough estimation of concentration profile by EFA. Using the estimate of $\mathrm{C}$, the $\mathrm{S}^{\mathrm{T}}$ matrices are calculated under appropriately chosen constraints by a least squares:

$$
\mathrm{S}=\left(\mathrm{D}^{\mathrm{T}} \mathrm{C}\right)\left(\mathrm{C}^{\mathrm{T}} \mathrm{C}\right)^{-1}
$$

In the next step using the estimate of $\mathrm{S}^{\mathrm{T}}$, calculate the $\mathrm{C}$ matrix under appropriately chosen constraints:

$$
\mathrm{C}=\left(\mathrm{D}^{\mathrm{T}} \mathrm{S}\right)\left(\mathrm{S}^{\mathrm{T}} \mathrm{S}\right)^{-1}
$$

From the product of $\mathrm{C}$ and $\mathrm{S}^{\mathrm{T}}$ an estimate of the original data matrix, $\mathrm{D}$ is achieved. Then new concentration or spectral profiles estimated from previous estimation using least square. These alternative least squares (ALS) are repeated until the convergence criterion is achieved. When the relative difference in fit is below a threshold value, the optimization is finished.

\section{Results and Discussion}

\section{Spectrophotometric studies}

\section{Interaction between morin and Bi(III)}

The UV-vis absorption spectra of morin in the presence of $\mathrm{Bi}(\mathrm{III})$ (with increasing concentration) were examined in the acetate buffer solution ( $\mathrm{pH} 3.2$ ) containing $50 \mathrm{mmol} \mathrm{L}^{-1}$ $\mathrm{KCl}$ (Figure 3). Morin has two maxima bands; at $252 \mathrm{~nm}$ (benzoyl of ring A) and the other at $350 \mathrm{~nm}$ (cinnamoyl of ring B). ${ }^{39,40} \mathrm{By}$ adding gradually $\mathrm{Bi}(\mathrm{III})$ ions into the morin solution at $\mathrm{pH} 3.2$ the absorption intensity of these two bands decreased gradually, and a new absorption peak appeared at $433 \mathrm{~nm}$. Moreover, the two isobestic points at 251 and $380 \mathrm{~nm}$ indicated that morin could form a complex with $\mathrm{Bi}(\mathrm{III})$ and the binding is homogeneous. There are two possible groupings on morin that can interact with $\mathrm{Bi}$ (III): the 2'-hydroxyl of ring $\mathrm{B}$ with the 1-oxo of ring $\mathrm{C}$ and 3 or 5-hydroxyls with the 4-carbonyl of ring $\mathrm{C}$ (Figure 1). The absorption peak at $350 \mathrm{~nm}$ has a slightly red shift (ca. $3 \mathrm{~nm}$ ) and a new absorption peak at $433 \mathrm{~nm}$ emerged suggesting that $\mathrm{Bi}(\mathrm{III})$ has bonded with the ring $\mathrm{B}$. The stoichiometry of the complex was determined using mole ratio method (Figure 4). The formation of a 2:1 ligand-metal complex extends the conjugated system, with the inclusion of the $\mathrm{C}$ rings, which leads to further molecular stabilization. ${ }^{41}$ Thus, the bonding of $\mathrm{Bi}(\mathrm{III})$ with ring $\mathrm{C}$ of morin produced an electronic redistribution between morin and $\mathrm{Bi}$ (III) ions, which resulted in an extended 4 bond system. On this basis, the $n-\pi^{*}$ electronic transition of morin changed to a $\pi-\pi^{*}$ one, with a consequent decrease in energy as reflected by the appearance of a new peak at the longer wavelength $(433 \mathrm{~nm})$. This relationship is also in accord with previous literatures ${ }^{42-44}$. Infrared spectra have also been used to validate the proposed complex structure. Table 1 shows the position of the most important IR bands of morin and its complex with bismuth(III). The comparison of these two spectra with each other shows important spectral changes, notably in $1400-1700 \mathrm{~cm}^{-1}$. The position of $\mathrm{v}(\mathrm{C}=\mathrm{O})$ is diagnostic for the involvement of $4 \mathrm{C}=\mathrm{O}$ chromophore in coordination. The complexation should lengthen the $\mathrm{C}-\mathrm{O}$ bond in the carbonyl group and lessen the force constant, which, in turn, may shift the IR band of the carbonyl group towards a smaller wavenumber. ${ }^{45}$ On the complexation of morin with $\mathrm{Bi}(\mathrm{III})$ ion, a shift of $\mathrm{v}(\mathrm{C}=\mathrm{O})$ is observed from $1662 \mathrm{~cm}^{-1}$ for morin to $1653-1652 \mathrm{~cm}^{-1}\left(\Delta v=12 \mathrm{~cm}^{-1}\right)$ for the complex. Hence, it may be assumed that the carbonyl group participates in binding the bismuth ion. Similar frequency values of this group are shown by the complexes of quercetin-5'-sulfonic acid with lanthanides, where the metal is bound via $3 \mathrm{C}-\mathrm{OH}$ and $4 \mathrm{C}=\mathrm{O}$ groups. ${ }^{46,47}$ In the spectra of the complex there also appear new bands due to the formation of the $\mathrm{M}-\mathrm{O}$ bond. These are the bands of the frequencies $1550-1546,811-805,508-492 \mathrm{~cm}^{-1}$. The $1550-$ $1546 \mathrm{~cm}^{-1}$ band is related to the formation of the chelate ring $>\mathrm{C}=\mathrm{O}---\mathrm{M}-\mathrm{O}-{ }^{48}$

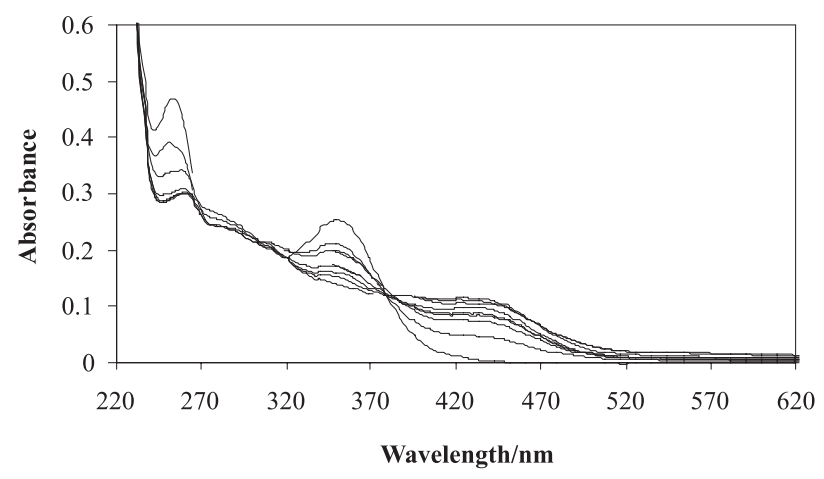

Figure 3. Absorption spectra of morin in the presence of Bi(III) at different concentrations. Conditions: $\left[\mathrm{Bi}^{3+}\right]=0,1.0,2.0,3.0,4.0,5.0,6.0,8.0,10.0$ and $50.0 \mu \mathrm{mol} \mathrm{L}^{-1}$ for curves $1-10$, and $C_{\text {morin }}=20.0 \mu \mathrm{mol} \mathrm{L}^{-1}, \mathrm{HOAc}-\mathrm{NaAc}$ buffer ( $\left.0.01 \mathrm{~mol} \mathrm{~L}^{-1}, \mathrm{pH} 3.2\right)$ plus $0.05 \mathrm{~mol} \mathrm{~L}^{-1} \mathrm{NaCl}$.

\section{Concentration profiles of morin and morin-Bi(III) complex} via $\mathrm{pH}$

To investigate the presence of different forms of the ligand and its complexes in a range of $\mathrm{pH}$ and to estimate the concentration profiles of these species along $\mathrm{pH}$, absorption spectra of solutions of ligand and complex 


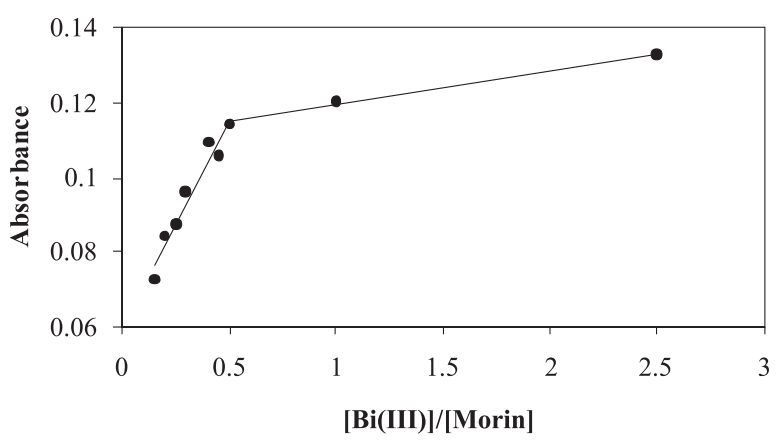

Figure 4. Mole ratio plot of morin in the presence of $\mathrm{Bi}(\mathrm{III})$ at different concentrations. Conditions: $\left[\mathrm{Bi}^{3+}\right]=0,1.0,2.0,3.0,4.0,5.0,6.0,8.0$, $10.0,20.0$ and $50.0 \mu \mathrm{mol} \mathrm{L}^{-1}, C_{\text {morin }}=20.0 \mu \mathrm{mol} \mathrm{L}^{-1}$, HOAc-NaAc buffer (0.01 $\mathrm{mol} \mathrm{L}^{-1}, \mathrm{pH} 3.2$ ) plus $0.05 \mathrm{~mol} \mathrm{~L}^{-1} \mathrm{NaCl}$.

Table 1. Position of the most important spectra bands in IR spectra of morin and its complex with bismuth (III)

\begin{tabular}{|c|c|c|}
\hline Type of bonds & Morin $/ \mathrm{cm}^{-1}$ & $\begin{array}{l}\mathrm{Bi}(\mathrm{III}) \text {-morin } \\
\text { complex } / \mathrm{cm}^{-1}\end{array}$ \\
\hline Stretching vibrations $\mathrm{OH}$ & $\begin{array}{l}3300 \\
2920\end{array}$ & 3160 \\
\hline Valence band $\mathrm{C}=\mathrm{O}$ & 1662 & 1650 \\
\hline $\begin{array}{l}\text { Stretching vibrations } \mathrm{C}=\mathrm{C} \text { in } \\
\text { aromatic ring, ring vibrations }\end{array}$ & $\begin{array}{c}1629 \\
1613 \\
- \\
1508 \\
1459\end{array}$ & $\begin{array}{c}- \\
1603 \\
1549^{*} \\
1507 \\
1443\end{array}$ \\
\hline Deformation vibrations $-\mathrm{C}-\mathrm{OH}$ & $\begin{array}{l}1379 \\
1310\end{array}$ & $\begin{array}{l}1370 \\
1321\end{array}$ \\
\hline Stretching vibrations $-\mathrm{C}-\mathrm{OH}$ & $\begin{array}{l}1257 \\
1227 \\
1201 \\
1173 \\
1104 \\
1085 \\
1011\end{array}$ & $\begin{array}{c}1257 \\
1238 \\
1198 \\
1172 \\
- \\
1095 \\
1008\end{array}$ \\
\hline $\begin{array}{l}\text { Deformation vibrations }-\mathrm{C}-\mathrm{H} \\
\text { outside plane, related to substitution } \\
\text { of aromatic rings of multiring } \\
\text { compounds }\end{array}$ & $\begin{array}{c}970 \\
876 \\
- \\
796 \\
703 \\
635 \\
585 \\
565 \\
\end{array}$ & $\begin{array}{c}975 \\
884 \\
805^{*} \\
- \\
705 \\
646 \\
587 \\
566 \\
\end{array}$ \\
\hline
\end{tabular}

were recorded separately in a $\mathrm{pH}$ range of 2.0 to 9.0 . The spectra were recorded in $0.5 \mathrm{~nm}$ intervals from 200 to $700 \mathrm{~nm}$. The obtained data formed two matrices D and D' for ligand and complex, respectively. Both of the matrices have the dimensions $1000 \times 8$, where rows are the number of wavelengths and columns are $\mathrm{pH}$. After obtaining the experimental data a principal component analysis was done on D and D'. The first two PCs from applying PCA on D and D' explained $99.38 \%$ and $99.71 \%$ of the variation in the data matrices respectively, so we can estimate the presence of two chemical components in $\mathrm{D}$ and also in $\mathrm{D}$ '. This means that ligand has two different forms along $\mathrm{pH}$ variation. The same conclusion can be made for complex data matrices D'.

In order to find a relatively good estimation of concentration profiles and pure spectra we used MCR-ALS procedure. MCR-AlS starts with a rough estimation of concentration or spectral profiles and iteratively improves them. The better initial estimation for concentration profiles can be achieved by EFA. To have an estimation for spectral profiles we can use the spectra recorded at the lowest and the highest $\mathrm{pH}$ were we guess that the main component is one of the either forms of the ligand or complex. Figure 5 represents the initial estimation of concentration profiles by EFA for ligand (Figure 5a) and complex (Figure 5b).
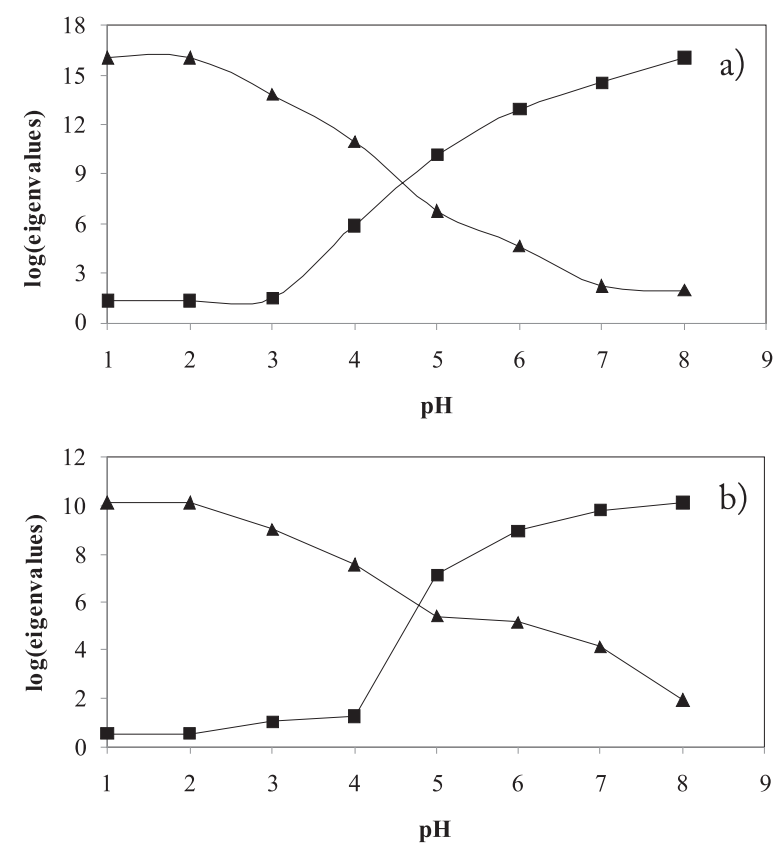

Figure 5. Initial estimation of concentration profiles obtained by EFA from ligand data matrices (a) and complex data matrices (b).

By these initial estimations the MCR-ALS procedure were done by the nonnegativity, unimodality and closure as constraints applied on concentration profiles and nonnegativity on spectral profiles. For closure constraint the total concentrations of to forms of ligand or complex constrained to be equal initial analytical concentration of ligand and complex $\left(100 \mu \mathrm{mol} \mathrm{L}{ }^{-1}\right)$. Figure 6 and Figure 7 illustrate the final results of MCR-ALS for ligand and complex, respectively. 


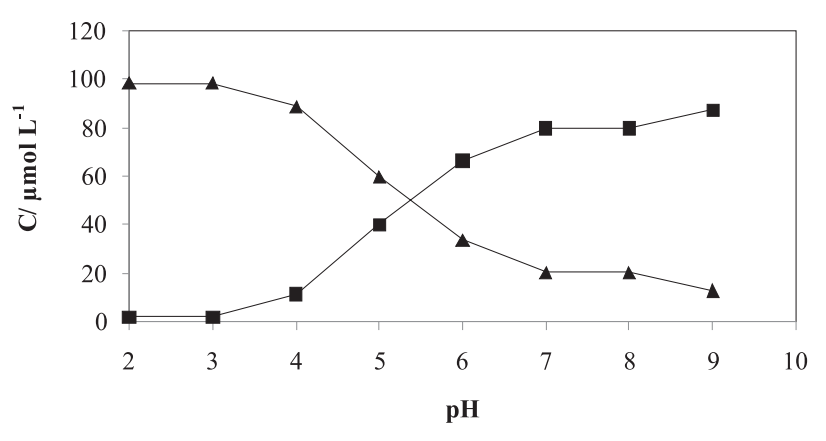

Figure 6. Final concentration profiles of ligand species obtained by MCRALS from estimated initial concentration profiles by EFA.

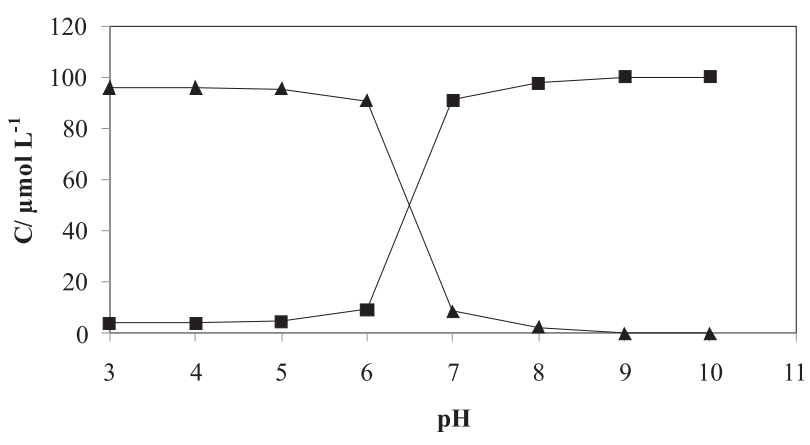

Figure 7. Final concentration profiles of complex species obtained by MCR-ALS from estimated initial concentration profiles by EFA.

Interaction of morin-Bi(III) complex with ct-DNA

UV-Vis absorption spectra were obtained by titration of a $1.0 \times 10^{-4} \mathrm{~mol} \mathrm{~L}^{-1}$ morin-Bi(III) complex solution with double strand DNA (ds-DNA) solution. The results are shown in Figure 8, shows a single absorption band of $433 \mathrm{~nm}$ for morin-Bi(III) complex in the absent of ct-DNA. Increasing the DNA concentration to the morin-Bi(III) complex cause decreasing the intensity of the absorption band. It is like the phenomenon yielded by the interaction between DNA and its typical intercalate. ${ }^{49}$

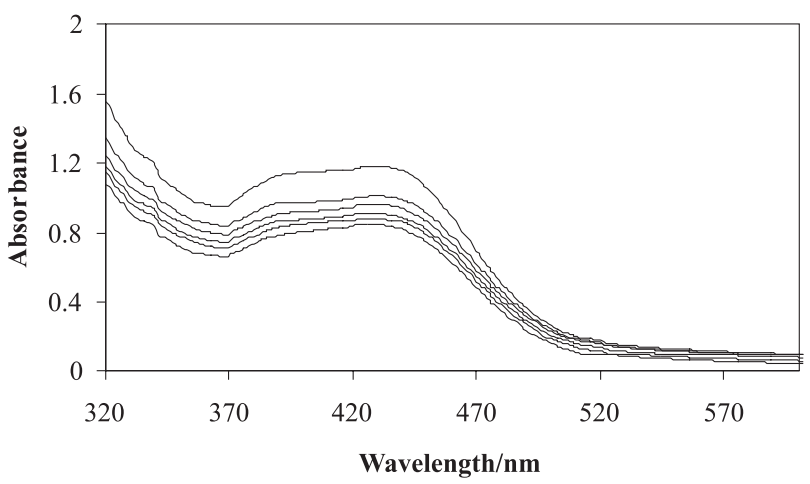

Figure 8. Absorption spectra of morin-Bi(III) complex in the presence of ct-DNA at different concentrations. $C_{\mathrm{DNA}}=0,29.3,53.0,80.0,103.5$ and $146.7 \mu \mathrm{mol} \mathrm{L}^{-1}$ for curves $1-6$, and $C_{\text {morin-Bi(III) }}=100 \mu \mathrm{mol} \mathrm{L}^{-1}$ in HOAc-NaAc buffer (0.01 $\mathrm{mol} \mathrm{L}^{-1}, \mathrm{pH}$ 3.2) plus NaCl.
Based on the variations of absorbance at the spectral band, the binding constant, $K$ of the complex-DNA can be obtained according to the following equation. ${ }^{50}$

$$
\frac{A_{0}}{A-A_{0}}=\frac{\varepsilon_{G}}{\varepsilon_{H-G}-\varepsilon_{G}}+\frac{\varepsilon_{G}}{\varepsilon_{H-G}-\varepsilon_{G}} \frac{1}{K[D N A]}
$$

Where " $A_{0}$ " and " $A$ " are the absorbance of the complex in the absence and presence of DNA, respectively, and $\varepsilon_{G}$ and $\varepsilon_{H-G}$ are their absorption coefficients, respectively. The result of fitting the experimental data with equation (4) is shown in Figure 9. It is suggested that the complex of morin with DNA is to be a kind of 1:1 complex. From a plot of $\mathrm{A}_{0} /\left(\mathrm{A}-\mathrm{A}_{0}\right) v s .1 /[\mathrm{DNA}]$, the ratio of the intercept to the slope gives the binding constant, $K=2.8 \times 10^{4} \mathrm{~mol}^{-1} \mathrm{~L}$.

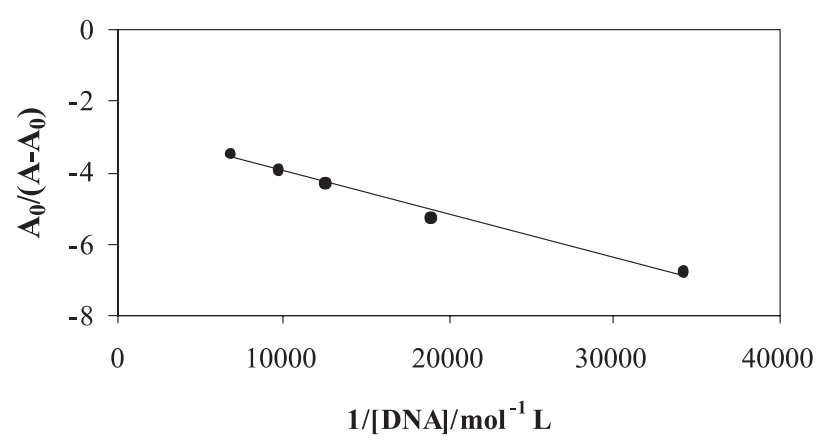

Figure 9. The plot of $\left(\mathrm{A}_{0} / \mathrm{A}-\mathrm{A}_{0}\right)$ versus 1/[DNA]. Conditions: HAc-NaAc buffer $\left(0.01 \mathrm{~mol} \mathrm{~L}^{-1}, \mathrm{pH} 3.2\right)$ plus $\mathrm{NaCl}, \mathrm{Bi}(\mathrm{III})=100 \mu \mathrm{mol} \mathrm{L}^{-1}, C_{\text {morin }}=$ $200.0 \mu \mathrm{mol} \mathrm{L}^{-1}$ (the absorbances are read at $445 \mathrm{~nm}$ ).

In order to clarify the portion of morin interacting with ct-DNA, the inclusion complex of MB-DNA was used for further study of the interaction site by spectroscopic method.

\section{Interaction of $M B$ with ct-DNA}

Absorption spectra of the MB dye in the absence and presence of DNA ( $\mathrm{pH}$ 3.2) showed a maximum at $662 \mathrm{~nm}$ (Figure 10). This absorption gradually decreased with the increasing concentration of ct-DNA and red shift is usually associated with molecular intercalation into the base stack of the ct-DNA. ${ }^{51}$ Those two observed spectral effects were attributed to a strong interaction between the electronic state of the intercalating chromophore and that of the DNA bases. The strength of this electronic interaction is expected to decrease as the third-order of the distance between the chromophore and the DNA bases. ${ }^{52}$ The large observed hypochromism during the interaction of the MB dye with the DNA, strongly suggest that the distance between the intercalated MB dye and the DNA bases is small. Thus, this is consistent with the rationalization that on intercalation of the MB dye into the DNA, the $\pi$ electrons of MB dye 
combine with the $\pi$ electrons of DNA's bases, and the empty $\pi^{*}$ orbital of the MB dye couple with the $\pi$ orbital of the bases. This facilitates a decrease in the energy of the $\pi-\pi^{*}$ electron transition, which is reflected in the observed red shift. At the same time the empty $\pi^{*}$ orbital is partially filled by electrons, reducing the $\pi-\pi^{*}$ transition probability, and this contributes to the hypochromic effect discussed above.

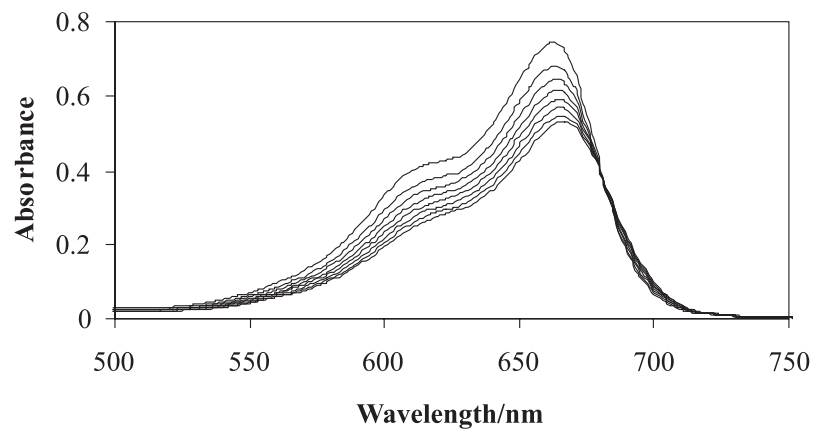

Figure 10. Absorption spectra of methylene blue in the presence of DNA at different concentrations. $C_{\mathrm{DNA}}=0.0,14.4,28.4,41.9,55.0,67.7,92.0$ and $103.5 \mu \mathrm{mol} \mathrm{L}{ }^{-1}$ for curves $1-8$, and $C_{\mathrm{MB}}=10 \mu \mathrm{mol} \mathrm{L}^{-1}$ in HOAc-NaAc buffer (0.01 $\left.\mathrm{mol} \mathrm{L}^{-1}, \mathrm{pH} 3.2\right)$ plus $0.05 \mathrm{~mol} \mathrm{~L}^{-1} \mathrm{NaCl}$.

\section{Competitive interaction of morin with $M B$-ctDNA}

A competitive interaction between morin and the MB-ctDNA system was observed by the addition of morin to a solution of methylene blue and DNA. As it is clearly shown (Figure 7), the intensity of the spectral band of MB-DNA at $662 \mathrm{~nm}$ gradually decreased with increasing morin concentration. Also a new peak at about 310-470 nm appeared which increased progressively in intensity. An isobestic point at $516 \mathrm{~nm}$ provides evidence that a new species was forming during the competitive interaction and that the reaction is homogebsorpneous. According to the observations, it seems that any exchange between morin with methylene blue bonded to DNA does not take place, because the molar absorption coefficient of free MB and MB-DNA are slightly different with each other. Therefore, a decrease in the absorbance intensity of MB may be due to the bonding of morin to DNA as a matrix effect. This phenomenon can be observed by comparing the maximum wavelengths of morin and morin-DNA (Figures 3 and 11). In addition unchanging in position of the band of morin in the presence and in the absence of DNA, suggest that morin has an electrostatic mechanism with the double helix of the DNA.

\section{Competitive interaction of morin-Bi(III) complex with $M B-c t D N A$}

The band intensity of MB-DNA at $662 \mathrm{~nm}$ gradually decreased with increasing concentration of morin-Bi(III) complex. This band almost shifted towards the blue end of

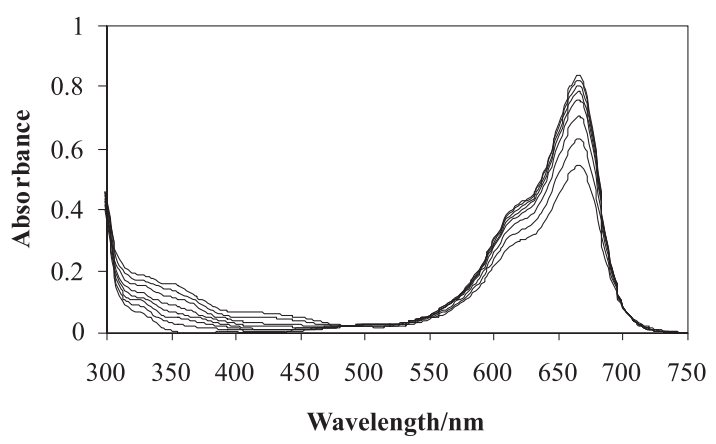

Figure 11. Absorption spectra of the competitive reaction between morin and methylene blue with DNA. $C_{\text {morin }}=0.0,2.0,4.0,6.0,8.0,10.0,14.0$ and $16.0 \mu \mathrm{mol} \mathrm{L}^{-1}$ for curves $1-8, C_{\mathrm{MB}}=10.0 \mu \mathrm{mol} \mathrm{L}^{-1}$ and $C_{\mathrm{DNA}}=20.0 \mu \mathrm{mol} \mathrm{L}^{-1}$ in HOAc-NaAc buffer (0.01 mol L-1, pH 3.2) plus $0.05 \mathrm{~mol} \mathrm{~L}^{-1} \mathrm{NaCl}$.

the spectrum with the appearance of a new peak at $415 \mathrm{~nm}$, which increased progressively in intensity (Figure 12). This new band was the sum of the changing absorptions of the MB dye and morin-Bi(III) complex. An isobestic point at $516 \mathrm{~nm}$ provides evidence that a new species was formed during the competitive interaction and thus the reaction is homogeneous.

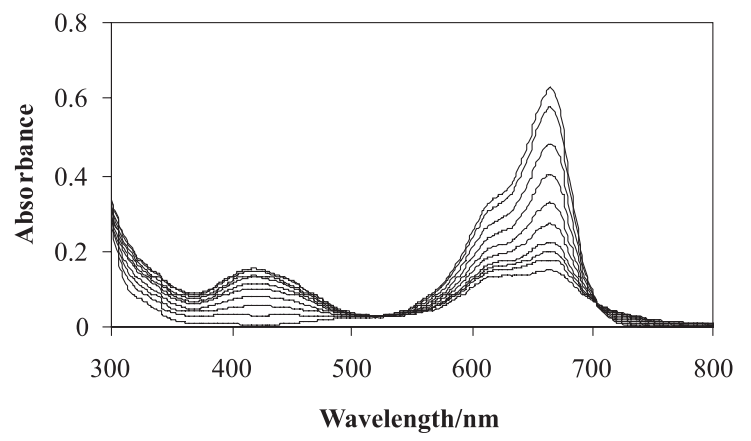

Figure 12. Absorption spectra of the competitive reaction between morin$\mathrm{Bi}(\mathrm{III})$ and methylene blue with DNA. $C_{\text {morin-Bi(III) }}=0.0,1.6,3.1,4.5,6.0$, 7.5, 8.7, 10.0, 11.3 and $12.5 \mu \mathrm{mol} \mathrm{L}^{-1}$ for curves $1-10, C_{\mathrm{MB}}=10.0 \mu \mathrm{mol} \mathrm{L}^{-1}$ and $C_{\mathrm{DNA}}=42.0 \mu \mathrm{mol} \mathrm{L}^{-1}$ in HOAc-NaAc buffer $\left(0.01 \mathrm{~mol} \mathrm{~L}^{-1}, \mathrm{pH} 3.2\right)$ plus $0.05 \mathrm{~mol} \mathrm{~L}^{-1} \mathrm{NaCl}$.

The maximum wavelengths of morin-Bi(II) complex in the presence and absence of DNA is different, indicating an intercalation mechanism. Addition of different amounts of morin-Bi(III) to MB-DNA causes change in the intensity and position of the bands, suggesting that the morin-Bi(III) complex intercalated into the double helix of the DNA.

\section{Electrochemical studies}

Electrochemical interaction of morin-Bi(III) complex with ctDNA

Typical CV (cyclic voltammetry) behavior of morin$\mathrm{Bi}$ (III) complex in the absence and presence of DNA is shown in Figure 13. Addition of DNA to morin-Bi(III) 
solution causes the peak currents of the $\mathrm{CV}$ waves (reduction of morin-Bi(III)) to diminish considerably. Additionally the peak potential $\mathrm{E}_{\mathrm{pc}}$ shifted to more negative values (from -0.52 to $-0.76 \mathrm{~V} v s$. $\mathrm{Ag} / \mathrm{AgCl}$ reference electrode) indicating that the action of morin-Bi(III) with DNA may be intercalation. ${ }^{53}$ The peak potential separations $\Delta \mathrm{E}_{\mathrm{p}}=\left|\mathrm{E}_{\mathrm{pc}}-\mathrm{E}_{\mathrm{pa}}\right|$ are beyond $200 \mathrm{mV}$ indicating an irreversible redox process.

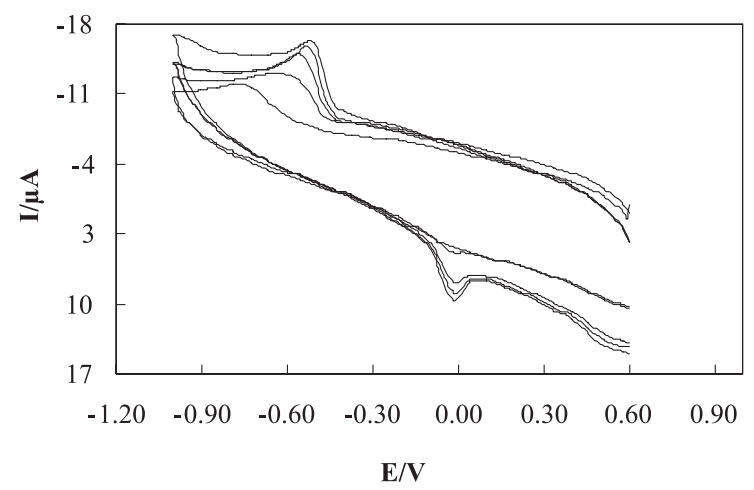

Figure 13. Cyclic voltammograms of morin-Bi(III) complex in the presence of different concentrations of DNA. $C_{\mathrm{DNA}}=0.0,35.2,52.8$, 140.8 and $200.0 \mu \mathrm{mol} \mathrm{L}^{-1}$ for curves $1-5$, and $C_{\text {morin-Bi(III) }}=100 \mu \mathrm{mol} \mathrm{L}^{-1}$ in HOAc-NaAc buffer (0.01 mol L-1, pH 3.2) plus $0.05 \mathrm{~mol} \mathrm{~L}^{-1} \mathrm{NaCl}$, scan rate $50 \mathrm{mV} \mathrm{s}^{-1}$.

\section{Electrochemical interaction of $M B$ with ctDNA}

A cyclic voltammogram of the MB dye probe (Figure 14) at a glassy carbon electrode exhibited cathodic and anodic peaks. The peak at approximately $-0.42 \mathrm{~V}$ corresponds to the reduction of $\mathrm{MB}$, and the one at $-0.14 \mathrm{~V}$ corresponds to the oxidation of MB. As the concentration of ct-DNA was increased no new peak current were formed, but a decrease in peak currents for both reduction and oxidation occurred with the reduction peak changing more significantly than the oxidation one. This suggests that there is a difference between the binding properties of $\mathrm{MB}$ and its reduced form to DNA. A slightly positive potential shift was observed for the reduction peak of $\mathrm{MB}$, which again suggests that the MB molecule has intercalated into the DNA.

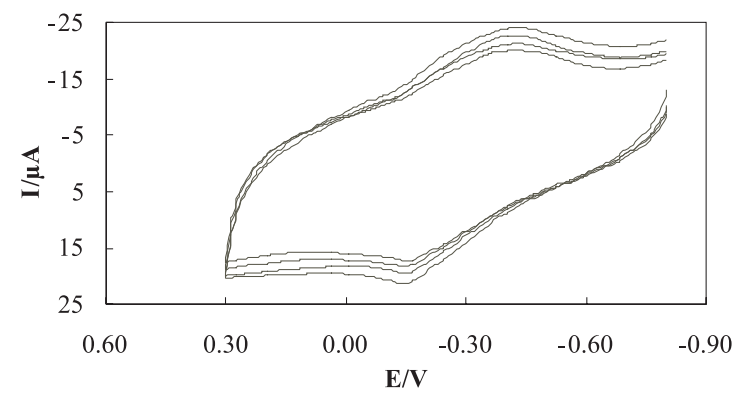

Figure 14. Cyclic voltammograms of methylene blue in the presence of different concentrations of DNA. $C_{\mathrm{DNA}}=0.0,17.6,35.2$ and $52.8 \mu \mathrm{mol} \mathrm{L}^{-1}$ for curves 1-4, and $C_{\mathrm{MB}}=50 \mu \mathrm{mol} \mathrm{L}-1$ in HOAc-NaAc buffer $\left(0.01 \mathrm{~mol} \mathrm{~L}^{-1}\right.$, $\mathrm{pH}$ 3.2) plus $0.05 \mathrm{~mol} \mathrm{~L}^{-1} \mathrm{NaCl}$, scan rate $50 \mathrm{mV} \mathrm{s}^{-1}$.

\section{Spectrofluorometry studies}

\section{Morin-Bi(III) and morin binding to DNA}

The fluorescence signal of Morin-Bi(III) is $c a .498 \mathrm{~nm}$ when excited at $428 \mathrm{~nm}$ whereas the signal for morin alone is $c a .500 \mathrm{~nm}$ when excited at $348 \mathrm{~nm}$. When the DNA solution was added to the morin-Bi(III) solution and to the morin alone solution, the fluorescence intensity for morin$\mathrm{Bi}(\mathrm{III})$ complex increased, whereas that for the alone morin solution decreased (quenched fluorescence) when those exited at the conditions given. Figures 15 and 16 show the fluorescence spectra of morin-Bi(III) complex and morin, respectively in the presence and absence of calf thymus DNA. The stronger enhancement in fluorescence intensity of morin-Bi(III) complex may be largely due to the increase of the molecular planarity of the complex and the decrease of the collisional frequency of the solvent molecules with the complex which is caused by the planar aromatic group of the complex stacks between adjacent base pairs of the DNA. Increasing of the molecule's planarity and decreasing of the collisional frequency solvent molecules with the complexes usually lead to emission enhancement. The binding of morin-Bi(III) to DNA leading to a marked

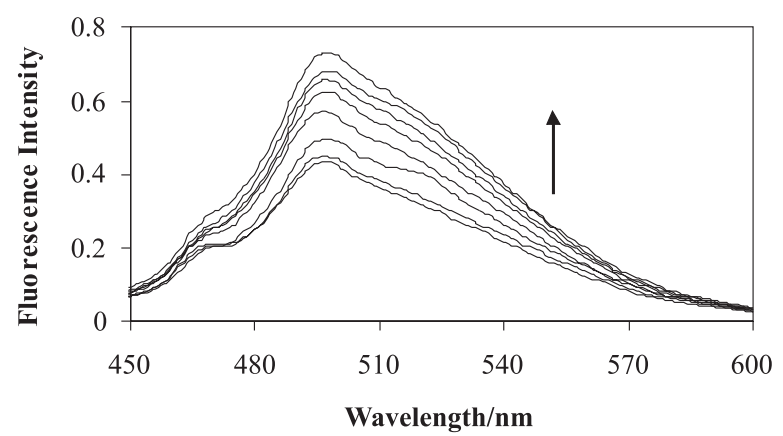

Figure 15. Emission fluorescence spectra of morin-Bi(III) complex with the addition of DNA. $C_{\mathrm{DNA}}=0.0,5.68,11.0,16.0,20.7,25.1,29.3$ and $37.1 \mu \mathrm{mol} \mathrm{L} \mathrm{L}^{-1}$ for curves $1-8$, and $C_{\text {morin-Bi(III) }}=100.0 \mu \mathrm{mol} \mathrm{L}^{-1}$ in HOAc-NaAc buffer $\left(0.01 \mathrm{~mol} \mathrm{~L}^{-1}, \mathrm{pH} 3.2\right)+0.05 \mathrm{~mol} \mathrm{~L}^{-1} \mathrm{NaCl}$, excitation wavelength $428 \mathrm{~nm}$.

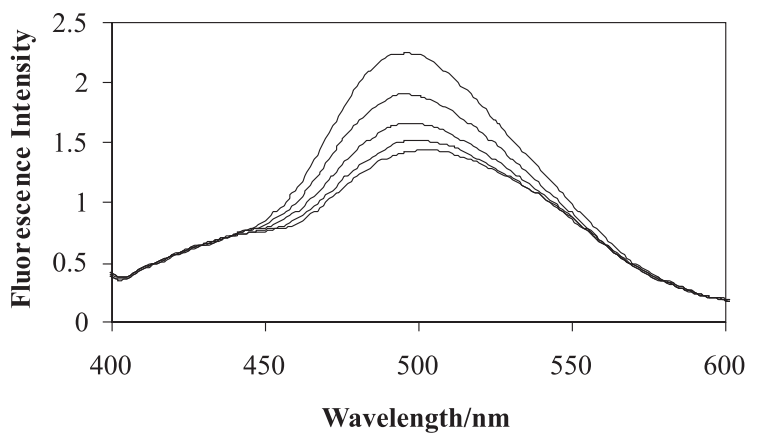

Figure 16. Emission fluorescence spectra of morin with the addition of DNA. $C_{\mathrm{DNA}}=0.0,8.7,17.3,25.6,41.9 \mu \mathrm{mol} \mathrm{L}^{-1}$ for curves 1-5, and $C_{\text {morin- }}=100.0 \mu \mathrm{mol} \mathrm{L}^{-1}$ in HOAc-NaAc buffer $\left(0.01 \mathrm{~mol} \mathrm{~L}^{-1}, \mathrm{pH} 3.2\right)$ plus $0.05 \mathrm{~mol} \mathrm{~L}^{-1} \mathrm{NaCl}$, excitation wavelength $348 \mathrm{~nm}$. 
increase in fluorescence emission intensity also agrees with observations for other intercalators. ${ }^{54,55}$. The emission quenching of morin in the presence of DNA may be caused by the fact that, morin being a small hydrophobic molecule and can be adsorbed by hydrophobic groups on the surface of DNA. ${ }^{56}$

Since morin-Bi(III) and morin alone display different emission spectral characteristics in the presence of DNA, it is apparent that more than a single binding mode exists for the two compounds. This conclusion is further supported by studying the effect of $\mathrm{MB}$ on the emission spectra of the DNA-morin-Bi(III) complex and DNA-morin systems.

\section{Effects of MB on the emission spectra of DNA-morin-Bi(III) and DNA-morin systems}

In order to investigate the mode of morin-Bi(III) complex and morin binding to DNA, MB has been employed in examination of the reaction, as $\mathrm{MB}$ presumably binds initially to DNA by intercalation. The experiment was carried out in a $3 \mathrm{~mL}$ solution of $2.8 \times 10^{-4} \mathrm{~mol} \mathrm{~L}^{-1} \mathrm{DNA}, 1.0 \times 10^{-5} \mathrm{~mol} \mathrm{~L}^{-1}$ morin-Bi(III) complex and $1.0 \times 10^{-5} \mathrm{~mol} \mathrm{~L}^{-1}$ morin titrated with the significant amounts of MB solution. Figures 17 and 18 show the fluorescence spectra of DNA-morin-Bi(III) complex and DNA-morin system, respectively, in the absence and presence of MB. When the concentration of $\mathrm{MB}$ was increased the fluorescence intensity of the DNA-morin-Bi(III) system decreased. With the addition of morin-Bi(III) complex to a solution of MB-DNA, some MB molecules were released into solution after an exchange with the morin-Bi(III) complex, and this resulted in fluorescence quenching. A progressive reduction of up to $72 \%$ in fluorescence was observed (Curves 1-7, Figure 17) together with a blue peak shift of $2 \mathrm{~nm}$. This supported the view that the complex intercalated into the DNA. ${ }^{54}$

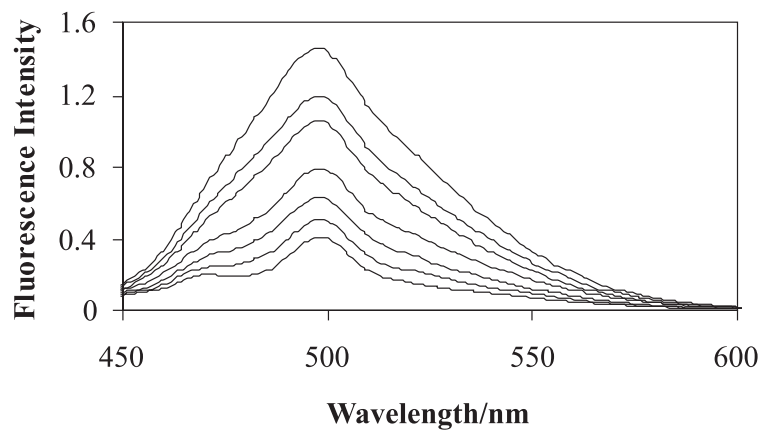

Figure 17. Emission fluorescence spectra of the competition between morin-Bi(III)-DNA complex and methylene blue. $C_{\mathrm{MB}}=0.0,1.6,3.1$, 4.6, 6.1, 7.5 and $8.8 \mu \mathrm{mol} \mathrm{L}{ }^{-1}$ for curves $1-7, C_{\text {morin-Bi(II) }}=10 \mu \mathrm{mol} \mathrm{L}^{-1}$ and $C_{\mathrm{DNA}}=28.4 \mu \mathrm{mol} \mathrm{L}^{-1}$ in HOAc-NaAc buffer $\left(0.01 \mathrm{~mol} \mathrm{~L}^{-1}, \mathrm{pH} 3.2\right)$ plus $0.05 \mathrm{~mol} \mathrm{~L}^{-1} \mathrm{NaCl}$, excitation wavelength $428 \mathrm{~nm}$.

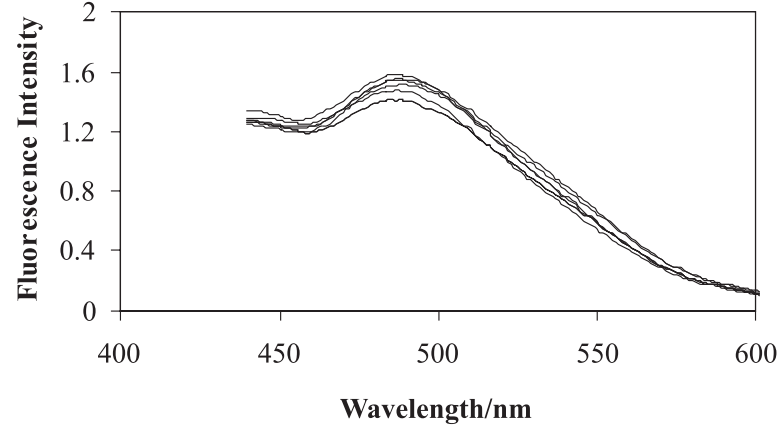

Figure 18. Emission fluorescence spectra of the competition between morin-DNA and methylene blue. $C_{\mathrm{MB}}=0.0,2.9,3.7,4.6,5.5,6.3$ and $8.0 \mu \mathrm{mol} \mathrm{L}-1$ for curves $1-7, C_{\text {morin }}=10 \mu \mathrm{mol} \mathrm{L}^{-1}$ and $C_{\mathrm{DNA}}=28.3 \mu \mathrm{mol} \mathrm{L}^{-1}$ in HOAc-NaAc buffer $\left(0.01 \mathrm{~mol} \mathrm{~L}^{-1}, \mathrm{pH} 3.2\right)$ plus $0.05 \mathrm{~mol} \mathrm{~L}^{-1} \mathrm{NaCl}$, excitation wavelength $348 \mathrm{~nm}$.

The fluorescence intensity of the DNA-morin system slightly changed as $\mathrm{MB}$ is added. Comparing these changes in the emission spectra of the DNA-morin-Bi(III) system with the DNA-morin system in the presence of MB, the difference is distinct. So, these two systems bind to DNA in different modes. The slightly emission quenching of morin in the presence of MB may be caused by the fact that, morin being a small hydrophobic molecule and can be adsorbed by hydrophobic group on the surface of DNA. ${ }^{57}$ Since Bi(III)-morin-DNA and morin-DNA display different emission spectral characteristics in the presence of $\mathrm{MB}$, it is apparent that more than a single binding mode for the two compounds exists.

Effects of morin-Bi(III) complex and morin on the emission spectra of DNA-MB system

Further support for the different modes of morin-Bi(III) and morin binding to DNA is given through the emission quenching experiment. Here MB was also employed as a probe. The experiment was carried out in a $3 \mathrm{~mL}$ solution of $2.7 \times 10^{-4} \mathrm{~mol} \mathrm{~L}^{-1} \mathrm{MB}, 2.8 \times 10^{-4} \mathrm{~mol} \mathrm{~L}^{-1}$ DNA titrated with $1.6 \times 10^{-6} \mathrm{~mol} \mathrm{~L}^{-1}$ morin-Bi(III) complex solution and $1.6 \times 10^{-6} \mathrm{~mol} \mathrm{~L}^{-1}$ morin solution, respectively. Figures 19 and 20 show the emission spectra of the DNA-MB system in the presence of morin-Bi(III) complex and morin, respectively. The emission intensity of the DNA-MB system increased as the concentration of morin-Bi(III) complex increased and the emission was slightly changed as morin was added to the DNA-MB system. An increase in the fluorescence intensity of MB-DNA due to an increased concentration of morin-Bi(III) complex may be due to the intercalation. This phenomenon indicates that morin-Bi(III) complex could not replace with MB from DNA-MB system due to the higher binding constant than DNA-morin-Bi(III). However, morin-Bi(III) complex could be intercalated into the DNA strains and increase the rigidity of the MB-DNA molecule. Consequently, an increase in the fluorescence 
intensity was observed with addition of the complex. Due to the electrostatic interaction of morin with DNA-MB, the emission intensity of this system changes slightly with the addition of morin (Figure 20).

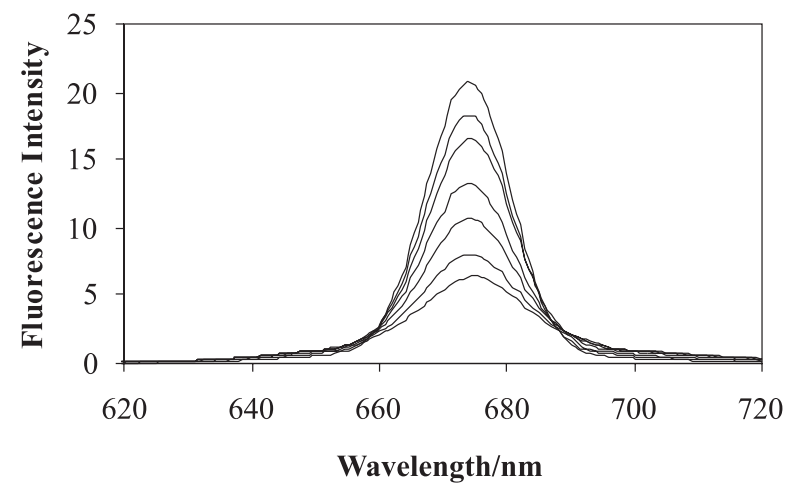

Figure 19. Emission fluorescence spectra of the competition between morin-Bi(III) complex and MB-DNA. $C_{\text {morin-Bi(III) }}=0.0,1.6,3.1,8.8$, 13.9, 16.2 and $18.4 \mu \mathrm{mol} \mathrm{L}^{-1}$ for curves $1-7, C_{\mathrm{MB}}=10 \mu \mathrm{mol} \mathrm{L}^{-1}$ and $C_{\mathrm{DNA}}=28.4 \mu \mathrm{mol} \mathrm{L}^{-1}$ in HOAc-NaAc buffer $\left(0.01 \mathrm{~mol} \mathrm{~L}^{-1}, \mathrm{pH} 3.2\right)$ plus $0.05 \mathrm{~mol} \mathrm{~L}^{-1} \mathrm{NaCl}$, excitation wavelength $620 \mathrm{~nm}$.

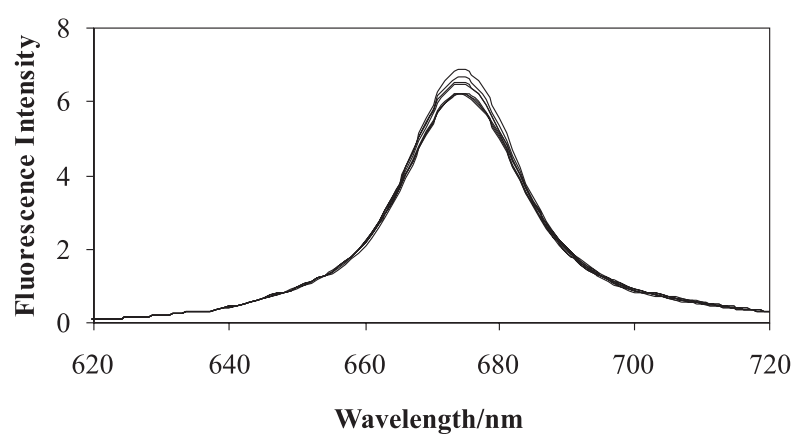

Figure 20. Emission fluorescence spectra of the competition between morin and MB-DNA. $C_{\text {morin }}=0.0,1.6,3.1,4.6,6.1,7.5,8.8$ and $10.1 \mu \mathrm{mol} \mathrm{L}^{-1}$ for curves $1-8, C_{\mathrm{MB}}=10 \mu \mathrm{mol} \mathrm{L}-1$ and $C_{\mathrm{DNA}}=28.4 \mu \mathrm{mol} \mathrm{L}^{-1}$ in HOAc-NaAc buffer $\left(0.01 \mathrm{~mol} \mathrm{~L}^{-1}\right.$, pH 3.2) plus $0.05 \mathrm{~mol} \mathrm{~L}^{-1} \mathrm{NaCl}$, excitation wavelength $675 \mathrm{~nm}$.

\section{Conclusion}

Based on our investigation, although both morin-Bi(III) complex and morin can bind to DNA, the nature of the binding was found to be different for each of them. In the presence and absence of the DNA, morin-Bi(III) complex shows different spectral characteristics which agree with those observed for other intercalators. This phenomenon suggests that the morin-Bi(III) complex binds to DNA mainly in the intercalating mode while the morin binds to DNA in a non-intercalating mode.

\section{Acknowledgement}

The authors gratefully acknowledge the financial support of this work by Research Council of Isfahan
University of Technology (IUT). The authors also thank Mr. Peyman Akhlaghi from Institute for Advanced Studies in Basic Sciences (IASBS) for his helpful guides.

\section{References}

1. Grguric-Sipka, S. R.; Vilaplana, R. A.; Perez, J. M.; Fuertes, M. A.; Alonso, C.; Alvarez, Y.; Sabo, T. J.; Gonzalez-Vilchez, F.; J. Inorg. Biochem. 2003, 97, 215.

2. Rauf, S.; Gooding, J. J.; Akhtar, K.; Ghauri, M. A.; Rahman, M.; Anwar, M. A.; Khalid, A. M.; J. Pharm. Biomed. Anal. 2005, 37,205

3. Chantal, C. L. M.; France, V. M.; Muriel, T.; Helene, S. M.; Jacques, M.; Marc, S. W.; Toxicology 1996, 114, 19.

4. Hollman, P. C. H.; Katan, M. B.; Food Chem. Toxicol. 1999, 37, 937.

5. Polissero, C.; Lenczowski, M. J. P.; Chinzl, D.; Davail, C. B.; Sumpter, J. P.; Fostier, A.; J. Steroid Biochem. Mol. Biol. 1996, $57,215$.

6. Fujiki, H.; Horinchi, T.; Yamashita, K.; Hakii, H.; Suganuma, M.; Nishino, H.; Iwashima, A.; Hirata, Y.; Sugimura, T.; In Plant Flavonoids in Biology and Medicine: Biochemical, Pharmacological and Structure Activity Relationships, Cody, V.; Middleton, E.; Harborne, J.B.; (eds.), Alan R. Liss, Inc.: New York, 1986, p. 429.

7. Deschner, E. E.; Ruperto, J.; Wong, G.; Newmark, H. L.; Carcinogenesis 1991, 12, 1193.

8. Elangovan, V.; Sekar, N.; Govindasamy, S.; Cancer Lett. 1994, 87, 107.

9. Chang, W. S.; Lee, Y. J.; Lu, F. J.; Chiang, H. C.; Anticancer Res. 1993, 13, 2165.

10. Zhu, X. X.; Mao, H. B.; Chin. Traditional Med. 1997, 28, 373.

11. Satyanarayana, S.; Dabrowiak, J. C.; Chaires, J. B.; Biochemistry $1992,31,9319$.

12. Nishio, A.; Uyeki, E. M.; Cancer Res. 1981, 43, 1951.

13. Kumar, C. V.; Barton, J. K.; Turro, M. J.; J. Am. Chem. Soc. 1985, 107, 5518.

14. Barton, J. K.; Danishefsky, A. T.; Golderg, J. M.; J. Am. Chem. Soc. 1984, 106, 2172.

15. Ling, L. S.; He, Z. K.; Zeng, Y. E.; Spectrochim. Acta, Part A 1999, 55, 1297.

16. Chen, W.; Turro, N. J.; Tomalia, D. A.; Langmuir 2000, 16, 15.

17. Mudasir, N.; Yoshioka, H.; J. Inorg. Biochem. 1999, 77, 239.

18. Solimani, R.; Int. J. Biol. Macromol. 1996, 18, 287.

19. Kapur, A.; Beck, J. L.; Sheil, M. M.; Rapid Commun. Mass Spectrom. 1999, 13, 2489.

20. Carcelli, M.; Mazza, P.; Pelizzi, C.; Zani, F.; J. Inorg. Biochem. 1995, 57, 43.

21. Zhang, N.; Zhang, X. L.; Zhao, Y. F.; Talanta 2004, 62, 1041. 
22. Raffaelli, A.; Pucci, S.; Desideri, I.; Bellina, C. R.; Bianchi, R.; Salvadori, P.; J. Chromatogr., A 1999, 854, 57.

23. Bale, M. J.; Yang, C. Pfaller, M. A.; Diagn. Microbiol. Infect. Dis. 1997, 28, 65.

24. Meric, B.; Kerman, K.; Ozkan, D.; Kara, P.; Erensoy, S.; Akarca, U.S.; Mascini, M.; Ozsoz, M.; Talanta 2002, 56, 837.

25. Usacheva, M. N.; Teichert, M. C.; Biel, M. A.; J. Photochem. Photobiol. B 2003, 71, 87.

26. Armstrong, R. W.; Kurucsv, T.; Strauss, V. P.; J. Am. Chem. Soc. 1970, 92, 3174.

27. Erdem, A.; Kerman, K.; Meric, B.; Ozsoz, M.; Electroanalysis 2001, 13, 219.

28. Ohuigin, C.; McConnell, D. J.; Kelly, J. M.; Van der Putten, W. J. M.; Nucl. Acids Res. 1987, 15, 7411.

29. Fujimoto, B. S.; Clendenning, J. B.; Delrow, J. J.; Heath, P. J.; Schurr, M.; J. Phys. Chem. 1994, 98, 6633.

30. Kelly, S. O.; Barton, J. K.; Jackson, N. M.; Hill, M. G.; Bioconjugate Chem. 1997, 8, 31.

31. Norden, B.; Tjerneld, F.; Biopolymers 1982, 21, 1713.

32. Britos, L.; Goyenola, G.; Orono, S. U.; Biochem. Mol. Biol. Educ. 2004, 32, 341.

33. Itoh, S.; Kaneco, S.; Ohata, K.; Mizuno, T.; Anal. Chim. Acta 1999, 379, 169.

34. Yamini, Y.; Chaloosi, M.; Ebrahimzadeh, H.; Talanta 2002, 56, 797.

35. Huang, C. Z.; Li, Y. F.; Feng, P.; Talanta 2001, 55, 321.

36. Windig, W.; Chemom. Intell. Lab. Sys. 1992, 16, 1.

37. Maeder, M.; Anal. Chem. 1987, 59, 527.

38. Nevea, S.; Juan, A. D.; Tauler, R.; Anal. Chim. Acta 2001, 446, 185.

39. Jovanovic, S. V.; Steenken, S.; Tosic, M.; Marjanovic, B.; Simic, M. G.; J. Am. Chem. Soc. 1994, 116, 4846.
40. Kang, J. W.; Zhuo, L.; Lu, X. Q.; Liu, H. D.; Zhang, M.; Wu, H. X.; J. Inorg. Biochem. 2004, 98, 79.

41. Torreggiani, A.; Tamba, M.; Trinchero, A.; Bonora, S.; J. Mol. Struc. 2005, 744, 759.

42. Brown, J. E.; Khodr, H.; Hider, R. C.; Rice-Evans, C. A.; Biochem. J. 1998, 330, 1173.

43. Yamamoto, N.; Moon, J. H.; Tsushida, T.; Nagao, A.; Terao, J.; Arch. Biochem. Biophys. 1999, 372, 347.

44. Hollstein, M.; Sidransky, D.; Vogelstein, B.; Harris, C. C.; Science 1991, 253, 49.

45. Silverstein, R. M.; Bassler, G. C.; Spectrometric Identification of Organic Compounds, John Wiley \& Sons, Inc.: New York, 1974.

46. Kopacz, M.; Nowak, D.; Microchem. J. 1993, 47, 338.

47. Kopacz, M.; Nowak, D.; Polish J. Chem. 2000, 74, 303.

48. Rao, C. N. R.; Chemical Applications of Infrared Spectroscopy, Academic Press: New York, 1963.

49. Takenaka, S.; Ihara, T.; Takagi, M.; J. Chem. Soc., Chem. Commun. 1990, 1485.

50. Ibrahim, M. S.; Shehatta, I. S.; Al-Nayeli, A. A.; J. Pharm. Biomed. Anal. 2002, 28, 217.

51. Long, E. C.; Barton, J. K.; Acc. Chem. Res. 1990, 23, 271.

52. Huang, C. Z.; Li, Y. F.; Feng, P.; Talanta 2001, 55, 321.

53. Pang, D. W.; Abruna, H. D.; Anal. Chem. 1998, 70, 3162.

54. Barton, J. K.; Goldberg, J. M.; Kumar, C. ,V.; Turro, N. J.; J. Am. Chem. Soc. 1986, 108, 2081.

55. Ni, Y.; Du, S.; Kokot, S.; Anal. Chim. Acta 2007, 584, 19.

56. Song, Y.; Kang, J.; Zhou, J.; Wang, Z.; Lu, X.; Wang, L.; Gao, J.; Spectrochimica Acta, Part A 2000, 56, 2491.

57. Song, Y.; Kang, J.; Wang, Z.; Lu, X.; Gao, J.; Wang, L.; J. Inorg. Biochem. 2002, 91, 470.

Received: April 15, 2008 Web Release Date: December 18, 2008 